\title{
A CONSIDERATION OF COPYRIGHT
}

\section{KENNETH B. UMBREIT $\dagger$}

The object of this article is to endeavor to ascertain the nature of the property interest involved in the word "copyright".

Copyright law is usually treated as an offshoot of patent law-as one of the two queer branches of our jurisprudence in which, by an exception depending on statute, intangible ideas are protected. The dissimilarities are more pronounced than the similarities. One gives a monopoly; the other merely a prohibition against copying-a very different thing. About the only similarity is that both deal with intangible rights against all the world but that is an element which they share with several other branches of the law. They do not even share a common origin in statute rather than custom for it is still debatable whether the original copyright statute-the Statute of Anne ${ }^{1}$-created a new right or merely limited a pre-existing common-law copyright. ${ }^{2}$

The most striking feature of copyright is that it is the only branch of the law which contemplates, at least in a normal state of affairs, the existence at the same time of two valid titles to the same piece of property. That is not true of patents. Both these branches of the law start with the proposition that to obtain a valid title to the property which he claims, the author or inventor must have "originated" it, but in copyright law the word "originate" is used in a strictly Pickwickian sense. It means, in copyright, that the author thought of what he seeks to have protected all by himself; not that he was the first to think of it. ${ }^{3}$ The work must be original with the author but it need not be original to the world. The validity of a copyright to a musical figure, for example, is not impaired merely because the same figure is

$\doteqdot$ Ph. B., I927, University of Chicago; LL. B., I930, Harvard University; member of New York bar; author of OUR ELEVEN CHIEF Justices (1938).

I. 8 ANNE, c. Ig (I709).

2. This question is discussed at length in the seriatim opinions in Jefferys v. Boosey, 4 H. L. Cas. 8r 5 (I854).

3. Fred Fisher, Inc. v. Dillingham, 298. Fed. I45 (S. D. N. Y. 1924); Jones Bros. Co. v. Underkoffler, I6 F. Supp. 729 (M. D. Pa. I936); Sheldon v. Metro-Goldwyn Pictures Corp., 8r F. (2d) 49 (C. C. A. 2d, I936), rev'g, 7 F. Supp. 837 (S. D. N. Y. I934), cert. denied, Metro-Goldwyn Pictures Corp. v. Sheldon, 298 U. S. 669 (I936); Arnstein v. Edward B. Marks Music Corp., 82 F. (2d) 275 (C. C. A. 2d, I936) ; Hartfield v. Peterson, 9I F. (2d) 998 (C. C. A. 2d, I937). Contra: Hein v. Harris, I83 Fed. I07 (C. C. A. 2d, Igro) ; Hoffman v. Le Traunik, 209 Fed. 375 (N. D. N. Y. I913); Norden v. Oliver Ditson Co., Inc., I3 F. Supp. 4I5 (D. Mass. I936). Hein v. Harris was expressly overruled in the Arnstein case and the Hoffman case can nc longer be considered law. In the Norden case the court was obviously thinking in patent terms which may have been due to the fact that a well-known patent firm represented the successful litigant. The chief authority relied on by the court in the Norden case was Cooper v. James, 213 Fed. 87I (N. D. Ga. I9r4), which was another case ir which patent principles were applied in the determination of a copyright question. 
to be found in an earlier copyrighted work; it must also appear that the author of the later work copied it from the first. ${ }^{4}$ Even a showing that the figure is to be found in a work in the public demesne does not make the copyright invalid. ${ }^{5}$ The test is subjective rather than objective. It means that the courts must delve into the subconscious and they have indicated their willingness to do so. ${ }^{6}$

The originality of patent law has another implication which is absent from copyright. To be patentable a device must be of an inventive nature not only as to the individual claiming the patent but as to all the world. The device must not only be new; it must also be the product of more than ordinary skill; it must, in short, be an invention. ${ }^{7}$ That is not true of copyright. Telephone directories, citators, law digests and other works in which there is no pretense of invention are copyrightable. ${ }^{8}$ In the early law there was a tendency to restrict copyright to works of true intellectual or artistic importance, but that disappeared with the successive decisions of the Supreme Court that a photograph of Oscar Wilde ${ }^{9}$ and a circus poster ${ }^{10}$ were copyrightable.

4. Fred Fisher, Inc. v. Dillingham, 298 Fed. I45 (S. D. N. Y. 1924). While not the leading case on this point the facts are such as to give the neatest illustration of the doctrine.

5. Ibid. The application of the doctrine in this case may be questioned on the specific facts. The figure in dispute was used in classical works of both Wagner and Schumann as well as in a work copyrighted prior to the plaintiff's copyright. Under those circumstances would it not be reasonable to suppose that the figure was part of the general fund of knowledge with which every professional musical composer might be expected to be familiar? If the defendant succeeded in finding, as he did, four prior uses, might there not be others? And might not the plaintiff's composer have heard this figure played, somewhere or other, and retained it in his memory? The court awarded only nominal damages and refused to award counsel fees.

6. .. . - if there was a subconscious memory of the story ... there might be an infringement." Harold Lloyd Corp. v. Witwer, 65 F. (2d) I, r6 (C. C. A. gth, I933), rev'g, Witwer v. Harold Lloyd Corp., 46 F. (2d) 792 (S. D. Cal. I930), cert. dismissed, 296 U. S. 669 (1935).

7. I WALKER, PATENTS (Deller's ed. I937) 36-7, rrT-II2.

8. 35 STAT. I076 (I909), I7 U. S. C. A. \$ 5 (a) (I926) expressly mentions, among the subjects of copyright, "directories, gazetteers, and other compilations." The copyright of a telephone directory was held valid in I Leon v. Pacific Telephone \& Telegraph Co., 9I F. (2d) 484 (C. C. A. 9th, 1937); of Shepard's citator system in Shepard v. Taylor, I93 Fed. 991 (C. C. A. 2d, I9I2). Questions of infringement of legal digests have been before the courts in too many cases to be mentioned in this note, for legal authors and publishers seem to be of an unusually litigious temperament.

9. Burrow-Giles Lithographic Co. v. Sarony, III U. S. 53 (I884).

ro. Bleistein v. Donaldson Lithographing Co,, IS8 U. S. 239 (I903). But see Higgins v. Keuffel, I40 U. S. 428, 43I (I89I). The cases, both before and after Bleistein $v$. Donaldson, on the copyrightability of advertisements are collected in Ansehl v. Puritan Pharmaceutical Co., 6I F. (2d) I3I (C. C. A. 8th, I932). Perhaps the coming of Bleistein v. Donaldson was foreshadowed by a decision of a circuit court that the words "Hi diddle diddle,

The cat and the fiddle,

The parrot and monkey too.

Bells they are ringing,

There's fighting and singing,

I wonder if dreams come true?"

tended to "promote the Progress of Science and useful Arts". Henderson v. Tompkins, 60 Fed. 758,762 (C. C. D. Mass. 1894 ). 
This distinction is especially important because of the overlapping between copyright and design patents. Thus a photograph of a design for a memorial has been held ${ }^{11}$ to be copyrightable as a design for a work of art under the statute ${ }^{12}$ although as a design for an object of manufacture it would seem more properly. to fall in the design patent category. The court in that case realized fully the difference between a copyright and a design patent ${ }^{13}$ but was willing to make the question of substance depend on the form in which the claimant had applied for protection. In doing so, it was acting in accordance with authority ${ }^{14}$ although there has been for a long time a rather ineffective statutory provision designed to prevent the copyrighting of "prints" intended primarily for use in connection with some other article. ${ }^{15}$ This state of the law may be explained in part by the early decisions on design patents which tended to apply copyright, rather than patent, conceptions in determining the patentability of designs. ${ }^{16}$ As an abstract question, there would seem to be more similarity between a design patent and a copyright than there is between a design patent and a mechanical patent. The fact that the law of design patents is following the precedents of mechanical patents rather than of copyrights ${ }^{17}$ is an accident of administration. It is due to their name and to their subjection to the jurisdiction of the Patent Office.

\section{"By-Products"}

The willingness of the courts to permit the copyrighting of works the protection of which would seem more properly to lie in the field of design patents is in accord with another well-established tendency of

Ir. Jones Bros. Co. v. Underkoffler, I6 F. Supp. 729 (M. D. Pa. I936).

12. 35 Stat. I077 (Ig09), I7 U. S. C. A. \$ 5 (g) (I926).

13. "The defendants introduced testimony and numerous exhibits to show that the essential elements of the 'Ruther' design were used prior to plaintiff's copyright. The true test of originality is whether the production is the result of independent labor or of copying." Id. at 73I.

14. Thus in Gerlach-Barklow Co. v. Morris \& Bendien, Inc., 23 F. (2d) I59 (C. C. A. 2d, I927), the plaintiff's copyright of a painting was upheld although it appeared that the plaintiff had purchased the painting solely for use in the manufacture of calendars. "If a painter originates and copyrights a work of art, can a chromo manufacturer copy the design . . ?" Falk v. Donaldson, 57 Fed. 32, 35 (C. C. S. D. N. Y. I893).

15. I8 STat. 79 (I874), I7 U. S. C. A. $\$ 63$ (1926). This section has been held to prevent the copyrightability of a picture of a polar scene used primarily in connection with water cups and coolers. Dixie Vortex Co. v. Lily-Tulip Cup Corp., Ig F. Supp. 5II (E. D. N. Y. I937).

I6. See, e. g., Gorham Co. v. White, I4 Wall. 5 Ir (U. S. I872) (Miller, Field and Bradley, JJ., dissented without opinion); Ripley v. Elson Glass Co., 49 Fed. 927 (C. C. S. D. Ohio, I892).

I7. "The solicitor for the Patent Office does not contend that appellant's bumperette does not present a new and distinctive appearance, but correctly states that this is not the only test of patentability. There must be, in addition, an exercise of the inventive or original faculty." In re Walter, $39 \mathrm{~F}$. (2d) 724 (C. C. P. A. I930). "It is not enough that a design be new, original, and ornamental. It must also be the result of the inventive faculty." In re Hall, $69 \mathrm{~F}$. (2d) 660,66 I (C. C. P. A. I934). 
copyright. This is the tendency to extend the protection of copyright to things which in their nature cannot be the subject of copyright. The fountainhead of this tendency is Falk $v$. Howell ${ }^{18}$ decided in the old circuit court shortly after the decision of the Supreme Court that there could be a copyright in a photograph of Oscar Wilde and ostensibly based on that decision. The facts of Falk $v$. Howell were that the plaintiff owned the copyright of a photograph of an actress sitting on the horn of a stage moon uttering some words from The Mikado. The defendant stamped a raised figure "like the picture", 19 but larger, on the leather backs and bottoms of chairs. This was held to be an infringement of the copyright. The case has been cited as good law in judicial opinions ever since but none of them seems to answer the numerous questions which come to mind.

Did the owner of the copyright to the operetta likewise have an action against the furniture manufacturer? It was probably the popularity of The Mikado which gave the picture value in the decoration of furniture. If so, should not the profit therefrom belong to the owner of the copyright of the operetta?" If there is a "furniture right" in the copyright of a photograph, should there not be a similar right in the copyright of an operetta or a novel? ${ }^{21}$ Could the chair itself have been copyrighted? ${ }^{22}$ How can a thing which is itself outside the field of copyright be the subject of copyright? Assuming that, as a result of the decision in Falk $v$. Horvell, the defendant purchased a license from the plaintiff, would it be necessary to affix notice of copyright to each chair? If, with the knowledge of the plaintiff, that was not done, would it be a dedication not only of the "furniture right" but of the right to rephotograph the photograph? ${ }^{23}$ In short, does not this decision run counter to the legislative intent as indicated

18. 37 Fed. 202 (C. C. S. D. N. Y. 1888).

19. Ibid.

20. The writer recognizes that, owing to a well-known situation, there was not likely to be an American copyright of The Mikado and, if anybody claimed one, he was not likely to be anxious to submit it to the hazards of litigation but this does not detract from the pertinency of the questions in the text.

2I. It has recently been held that the owner of the copyright in a novel (but not its illustrations) has no rights in the illustrations. Harris v. Coca-Cola Co., $73 \mathrm{~F}$. (2d) 370 (C. C. A. 5th, 1934); cf. Champney v. Haag, I2I Fed. 944 (C. C. E. D. Pa. I903). 22. "If this is good law it should work both ways, and it would follow that a copyrighted chair back in relief would be infringed by a photograph of the chair back." Bracken v. Rosenthal, I5I Fed. I36, I37 (C. C. N. D. I11. I907), referring to Falk $v$. Howell.

23. It was held in an old Irish case, Thurner v. Robinson, Io Ir. Ch. I2I (I860), which has been frequently cited in this country, that if $A$ poses a group of living figures in imitation of a painting and photographs the group, the photograph is an infringement of the copyright in the painting. However, it was subsequently held, Hanfstaengl v. Empire Palace, (I894) $2 \mathrm{Ch}$. I, that the living group itself would not infringe the copyright of the picture which the group attempted to represent. An opposite result was reached under the English Copyright Act of IgII, I \& 2 GEo. V, c. 46 , in Bradbury, Agnew \& Co. v. Day, 32 T. L. R. 349 (K. B. I916). 
by the statutory provision for design patents and, above all, by the statutory provision that "no prints . . . designed to be used for any other article of manufacture shall be entered under the copyright law"? 24

The basic principle of Falk $v$. Howell-the principle that copyright may protect objects which cannot themselves be copyrightedis well established. ${ }^{25}$ That principle is derived from a preference for form over substance which is reminiscent of the days when substantive rights depended on the forms of the common-law writs. Its limitations are likewise matters of form. Among works which are clearly copyrightable the extent and number of what might be termed the "legal by-products" of a copyright are frequently dependent on the form in which the copyrighted idea (for whatever the courts may say, ideas, in the ordinary meaning of the word, are what the copyright law protects) is first embodied.

For some reason which is not entirely clear, cartoons, whether still or animate, are the most advantageous form in which to embody anything designed for copyright. In part, this may be due to the similarity of cartoons to photographs, a similarity which has made cartoons the special beneficiary of the doctrine that a photograph can be the subject of copyright. The reading of almost any judicial opinion of the years immediately succeeding the Sarony case, ${ }^{26}$ the case in which that doctrine was established, will indicate both the surprise with which that doctrine was received and the general feeling that its true interpretation was that the Supreme Court intended to enlarge the field of copyright. In part, it may be due to the comparative newness of most methods of reproducing copies of pictures of any kind. Books are the oldest form of work known to copyright law and, consequently, when the modern growth of copyright by-products began, books had to contend with a number of well-established doctrines inimical to that growth. Thus, while it required statutory action both in the United States and England to establish the existence of dramatic rights in novels, ${ }^{27}$ the existence of a similar right in comic strips has apparently been conceded in this country without argument. ${ }^{28}$

While our statute now enumerates, among the rights conferred by the granting of a copyright, the right "to dramatize it if it be a non-

24. I8 Stat. 79 (I874), I7 U. S. C. A. \$63 (I926).

25. See infra notes 42,43 .

26. Lithographic Co. v. Sarony, III U. S. 53 (I884).

27. See Fitch v. Young, 230 Fed. 743,745 (S. D. N. Y. I9I6), aff'd, 239 Fed. ro2I (C. C. A. 2d, I9I7); Copinger, Copyright (7th ed. I936) I30.

28. Hill v. Whalen \& Martell, 220 Fed. 359 (S. D. N. Y. I9r4), cited with approval in King Features Syndicate v. Fleischer, 299 Fed. 533, 536 (C. C. A. 2d, 1924); see Empire City Amusement Co. v. Wilton, I34 Fed. $3_{32}$ (C. C D. Mass. Ig03). 
dramatic work", 29 it is hardly necessary to point out how readily a court, had it been so disposed, could have construed the expression "nondramatic work" to exclude cartoons. In the very next clause of the statute there is a reference to "a novel or other nondramatic work" 30 indicating rather plainly that the legislature, in conferring the "dramatization right", was thinking of nondramatic works of a literary character. Cartoons, either still or animate, are not even mentioned in the statutory classification of works entitled to copyright. ${ }^{31}$ The ease with which the law has conceded dramatic rights in cartoons is in sharp contrast with a recent decision ${ }^{32}$ denying the existence of broadcasting rights in a poem.

This liberality towards cartoons appears not only in the concession of dramatic rights but in the scope of those dramatic rights. Thus, in the case in which the existence of such rights was first definitely conceded, ${ }^{33}$ the facts were such that it may be doubted whether a court would have found infringement if it had been a question of the illegal use of the dramatic rights to a novel. There was no plagiarism of plot. The plagiarism, if any, was a plagiarism of character. The opinion does not put the decision on that ground and the facts as they appear in the report are not sufficient to warrant an interpretation of the case as based on a plagiarism of character. The facts were simply that the defendant produced and exhibited a dramatic performance called In Cartoonland, containing two characters named, respectively, "Nutt" and "Giff", and bearing some general resemblance to the cartoon characters "Mutt" and "Jeff". The successful plaintiff was the exclusive licensee of dramatic rights from the owner of the copyright to the cartoon comic strips Mutt and Jeff. ${ }^{34}$

One explanation of the Mutt and Jeff case is that it is based on some doctrine outside copyright but related to trade-marks. That is an interpretation which the courts are loath to accept. In I9O3 the argument was advanced on behalf of Rudyard Kipling that he owned

29. 35 Stat. 1075 (I909), I7 U. S. C. A. \$ I (b) (I926).

30. Ibid.

3I. 35 Stat. 1076 (Ig09), 37 STAT. 488 (I9I2), I7 U. S. C. A. § 5 (Ig26).

32. Kreymborg v. Durante, 2I U. S. Pat. Q. 557 (S. D. N. Y. 1934), on rehearing, 22 U. S. Pat. Q. 248 (S. D. N. Y. I934). The importance not only of the form of the work but of the manner in which it is first presented to the public is strongly brought out by the opinion in this case on rehearing. "If a poem were first spoken or rendered at a gathering . . . it would be an address in poetry and if copyrighted would be secure against unauthorized delivery later on by others . . . the plaintiff's poems were first published in book form. They do not therefore correspond to or resemble a lecture, sermons or address." Id. at 249. From this it would appear that all well-advised poets should read their poems from a soapbox before they permit them to be printed.

33. Hill v. Whalen \& Martell, 220 Fed. 359 (S. D. N. Y. Igr4).

34. There is a discussion of infringement of character in Nichols v. Universal Pictures Corporation, 45 F. (2d) IIg, I2I (C. C. A. 2d, I930), aff'g, 34 F. (2d) I 45 (S. D. N. Y. 1929), cert. denied, 282 U. S. 902 (I93I). The rules there laid down do not cover the case discussed in the text. 
the trade-mark to an elephant's head when used as a design on the cover of his books. "The proposition that an author can protect his writings by a trade-mark", the court answered, "is unique. . . . It is certainly offensive to the aesthetic and poetic taste to place such poems as the 'Recessional' and 'The Last Chantey' in the same category with pills and soap." ${ }^{35}$ The same aesthetic sense may not have troubled the court when the question was whether "Mutt" and "Jeff" could be trade-marks, but if copyright is a body of law such considerations should be, but are not, irrelevant. In a subsequent case, in which the words "Nick Carter" had actually been registered as a trade-mark for periodicals it was held that the registrant, who was also the publisher of the uncopyrighted Nick Carter series, could not prevent the exhibition of a motion picture entitled Nick Carter, the Great American Detective, Solving the $\$$ Too,0oo.oo Jewel Mystery. ${ }^{36}$

The courts at first even refused to recognize ownership of a cartoon character when unaccompanied by copyright. ${ }^{3 \tau}$ This last case and the Nick Carter case can be distinguished from the Mutt and Jeff case on the ground of the presence or absence of copyright. To adopt this distinction is to obscure the point which is whether copyright gives a property interest in the names of fictional characters distinct from the property interest in themes, plots and characters properly so called. $^{38}$ If it does, what has become of the time-honored rule that there can be no copyright in a title? The indications are that the courts will not adopt this distinction, for the latest case holding that there is a property interest in the name of a fictional character bases that property interest on the doctrines of unfair competition. ${ }^{39}$

This is arguing in a circle. The opinions in the cases on copyright by-products are full of references to unfair competition and of discussions whether what the defendant is doing "will materially reduce the demand for the original". ${ }^{40}$ This neatly ignores the question of what is the "original". The unsatisfactory nature of this type of reasoning is most apparent in the decisions underlying what has come to be an important industry - the manufacture of novelties based on animated cartoons. ${ }^{41}$

35. Kipling v. G. P. Putnam's Sons, r20 Fed. 631, 635 (C. C. A. 2d, I903) ; cf. Doan v. American Book Co., I05 Fed. 772 (C. C. A. 7th, Ig0I).

36. Atlas Mfg. Co. v. Street \& Smith, 204 Fed. 398 (C. C. A. Sth, I913).

37. Outcalt v. New York Herald, I46 Fed. 205 (C. C. S. D. N. Y. Ig06).

38. See supra note 34 .

39. Patten v. Superior Talking Pictures, 8 F. Supp. I96 (S. D. N. Y. I934).

40. Hill v. Whalen \& Martell, 220 Fed. 359, 360 (S. D. N. Y. I914). It should be mentioned in passing that the question whether the defendant's actions did any economic harm to the plaintiff is not always material in copyright infringement cases. Fred Fisher, Inc. v. Dillingham, 298 Fed. I45 (S. D. N. Y. 1924).

4x. The writer is informed on good authority that in the case of one of the largest manufacturers of animated cartoons the revenue from these "rights" makes the difference between profit and loss. 
The basic judicial decision in this field is a holding that a toy horse labelled "Spark Plug" and made to resemble generally the cartoon character of that name infringed the copyright in the cartoons. ${ }^{42}$ The next decision ${ }^{43}$ went a step further for, so far as appears from the report, the doll, in this case, was not labelled with the name of the cartoon character but merely had a visual resemblance to an animated cartoon character. This would indicate that the complainant should more properly have sought protection with a design patent than with a copyright. Such a solution may be correct, but it would seem, at least in some instances, that what is being protected here is really a third type of property not properly cognizable under either the design patent or the copyright statute.

Is it really the design which gives value to a doll modelled to resemble the animated cartoon character Betty Boop? ${ }^{44}$ Would the sales of the doll have been as extensive if the creator of the character had embodied his idea originally in a doll instead of an animated cartoon character and had obtained a design patent for the doll? Certainly the court that found the doll to be an infringement of the animated cartoon did not have the evidence before it with which to answer that question, but it is a pretty safe guess that a jury of business men would have answered it in the negative.

It is fairly clear that what is being protected in these cartoon by-product cases is neither an idea, a character, nor a design but a popularity value, a sort of psychological property. This is also the true nature of the business value which was protected in the early cases on photographs. ${ }^{45}$ The courts determined that those photographs had artistic value but it is quite plain on the face of the record that it was not the artistic value which was responsible for the litigation in any of those cases. In each of those cases the photograph involved was a photograph of a celebrity. In the Sarony case it was a photograph of Oscar Wilde; in the three other cases of popular actresses. Did any member of the Supreme Court seriously believe that the 85,000 copies of a photograph of Oscar Wilde, stated in the opinion to have been sold, were sold because of the photographer's artistic skill? Is it a sound judicial policy to allow substantive rights of great value-in this case an exclusive right to sell photographs of a widely advertised celebrity-to depend on an incidental and possibly

42. King Features Syndicate v. Fleischer, 299 Fed. 533 (C. C. A. 2d, I924).

43. Fleischer Studios v. Freundlich, 73 F. (2d) 276 (C. C. A. 2d, I934), cert. denied, 294 U. S. 7 I7 (I935).

44. Ibid.

45. Burrow-Giles Lithographic Co. v. Sarony, IIr U. S. 53 (I884); Falk v. Brett Lithographing Co., 48 Fed. 678 (C. C. S. D. N. Y. I89I); Falk v. Gast Lith. \& Eng. Co., 54 Fed. 890 (C. C. A. 2 d, 1893), aff'g, 48 Fed. 262 (C. C. S. D. N. Y. I89r). 
fictitious factor-in this case the presumed artistic skill of the photographer? This artistic skill is not a question of fact in each instance; it is a legal conclusion based on the taking of the photograph from life. In discussing any decision, therefore, it must be considered as an unverified hypothesis, as a legal fiction.

It is difficult to rationalize a legal principle which assigns the economic value in a photograph of a celebrity to the photographer rather than to the celebrity. ${ }^{46}$ It must be obvious that there will be celebrities who will attempt to avoid its effects by means of contracts under which they will agree to give exclusive sittings to particular photographers in exchange for a portion of this economic value. It would seem that the contribution of the photographer to the photograph of a celebrity could much more properly be protected by some doctrine in the nature of that by which news is protected ${ }^{47}$ than by copyright.

The trade-mark and unfair competition explanations of these animated cartoon by-products cases is inapt for another reason. The element of fraud on the public is absent. No one can seriously argue that the reason the public buys a doll modelled after Betty Boop or Spark Plug is because of the confidence the public has in the manufacturing skill of the producers of the cartoons which made those characters famous. We are dealing here with a type of property unknown to the older economics on which the law is based. It does not represent a "practical" value based on the assumption that the "trademark" is a warranty of quality; it represents a sentimental value based on the fact that the article bears the "trade-mark". It is not based on any copyright value in the traditional sense, for it has no relation to art or to the beauty or utility of design. It is capable of indefinite expansion for the courts have so far been asked to pass on only a small number of the different kinds of "franchises" which are recognized commercially. ${ }^{48}$ Nor does there seem to be any reason why the legal

46. It has recently been held that the owner of real estate has no rights in a photograph of his property. Cory v. Physical Culture Hotel, I4 F. Supp. 977 (W. D. N. Y. 1936). Putting this case beside Bradbury, Agnew \& Co. v. Day, 32 T. L. R. 349 (K B. I9I6), cited stpra note 23 , we reach the rather surprising result (under substantially similar statutory provisions) that a photographer can prevent the reproduction of a photograph by a living group picture, but the producer of a living group picture cannot prevent its reproduction by means of a photograph.

47. Board of Trade of Chicago v. Christie, I98 U. S. 236 (I905); International News Service v. Associated Press, 248 U. S. 2I5 (Igr8); National Tel. News Co. v. Western Union Tel. Co., IIg Fed. 294 (C. C. A. 7th, I902) ; Illinois Commission Co. v. Cleveland Tel. Co., Irg Fed. 30r (C. C. A. 7th, I902); Board of Trade of Chicago v. Tucker, 22I Fed. 305 (C. C. A. 2d, I915), aff'g, 221 Fed. 300 (W. D. N. Y. I9I4); cf. Chicago Record-Herald Co. v. Tribune Ass'n, 275 Fed. 797 (C. C. A. 7th, Ig2I). But see Baker v. Selden, Ior U. S. 99, I05 (I880).

48. "'Doing the Dopey', a new dance craze conceived from 'Snow White and the Seven Dwarfs' (RKO), was introduced here last week by Johnny Hamp's band, cur- 
recognition of this popularity value should be limited to cartoons ${ }^{49}$ or even to subjects capable of copyright.

\section{"Dertved Products"}

One reason for the expansion of legally recognized by-products of a cartoon copyright is that the cases which have so far arisen have been of deceiving simplicity. It is not difficult for a court to look at a "Spark Plug" doll and a "Spark Plug" cartoon, to learn that the doll was labelled "Spark Plug" and to find copyright infringement. There is no need to determine whether the maker of the doll has himself contributed any artistic skill; it is admitted on all sides that any competent mechanic could have looked at the cartoon and made the doll. There is another group of cases-those in which the alleged infringer has himself contributed artistic skill (or whatever we wish to call the type of talent which the copyright statute is designed to protect) to the alleged infringing work. Such a work is more than a mere byproduct; it does not flow without effort from the original copyright; it does not seem properly to be described as a "version". ${ }^{50}$ It is in dealing with these "derived products" that we feel most the need of a satisfactory definition of copyright.

The concept of "copying", carried over from the days when copyright concerned itself solely with the book trade, can still be used to determine whether a doll infringes a cartoon. It is of doubtful value when we deal with a by-product which is itself an original. On the one hand we are faced by the rule laid down by Justice Holmes in Bleistein v. Donaldson that "Personality always contains something unique. It expresses its singularity even in handwriting, and a very modest grade of art has in it something irreducible, which is one man's alone. That something he may copyright" ${ }^{51}$, on the other by the factual situation that every copyrighted work is in a sense a byproduct, a derivative. "There is not so poor a book in the world", said Dr. Johnson, "that would not be a prodigious effort were it wrought out entirely by a single mind." 52

rent in Book-Cadillac Hotel's Book Casino. Hamp previously had received permish from RKO and Walt Disney." Variety, March 23, I938, p. I, under a Detroit date line. Is there a dance "right" in an animated cartoon?

49. "Alan McIvor, a Canadian composer, has written a symphony based on Frank L. Packard's adventure story, 'The Red Ledger'. The title of the symphony is ' $2 \mathrm{~T} / 2$ Dominic Court'. Mr. Packard's next book, 'More Knaves Than One', will be issued on Sept. 9 by Doubleday, Doran \& Co. We trust that Mr. Packard's literary agent is looking out for the symphony rights, and that other authors and their agents will keep an eye on developments in this new literary by-product." New York Times Book Review, Aug. I4, 1938, p. I4, col. 3.

50. Thus the statute, 35 STAT. 1075 (Ig09), I7 U. S. C. A. \$ I (b) (1926), gives to he owner of the copyright to a literary work the right to "make any other version hereof".

5I. I88 U. S. 239,250 (Ig03).

52. I Boswel,, JoHnson (National Library ed.) 526. 
Speaking generally, every work of a literary or artistic nature is copyrightable yet every copyrightable work is derived from a work of a copyrightable nature. The courts have recognized that the possibility of truly original story-telling is remote. ${ }^{53}$ At least one judge has recognized that such originality is not a necessary ingredient in genius. $^{54}$ It is universally conceded that there may be two versions in the same medium of a copyrighted work in another medium, each of which versions may be the subject of independent copyright, both of which may be infringements of the prior copyrighted work in another medium and which versions may or may not be infringements of each other. When we add to this the factual situation that a copyrightable work never comes into being in a vacuum-that every copyrightable work reflects some derivation-and the legal situation, based on the peculiar copyright concept of "originality", that there may be two valid copyrights of the same property, it is evident that the problem of determining what derived products constitute infringements is not an easy one.

A reading of the cases will confirm the conclusion reached from this abstract consideration. The problem has been immensely complicated by the refusal of the courts to admit that it is difficult. They assume that it is merely a question of "copying", but a "copying" of what? Certainly not a "copying" as the earlier judges would have understood it.

". . . the right is to that arrangement of words which the author has selected to express his ideas." 55

"The subject of property is the order of words in the author's composition; not the words themselves, they being analogous to the elements of matter, which are not appropriated unless combined; nor the ideas expressed by those words, they existing in the mind alone, which is not capable of appropriation." 56

53. "There probably is not a play in the history of the world that has not something that is to be found in some previous publication, either in drama, or in fiction or poetry, or some form of literary endeavor. . . ." Underhill v. Belasco, 254 Fed. 838, 842 (S. D. N. Y. I918).

54. ". . - it is the themes which catch the popular fancy, but their invention is not where musical genius lies, as is apparent in the work of all the great masters." Arnstein v. Edward B. Marks Music Corporation, 82 F. (2d) 275, 277 (C. C. A. 2d, 1936). Cf "Every critic of Bach has commented on his inability to compose hymn-tunes of his own. - . - Bach went to other composers for initial themes and transcribed othe1 men's music because it roused his own creative activity. . . . In all this Bach is : typical, traditional artist. Shakespeare never invented a plot, and re-wrote old plays Molière went to the farces of the Italian comedians; and Chaucer, after thirty years 0 : imitation and translation, turned to the fabliaux of the popular minstrels." EDWARDS PlagrarisM (I933) 27-29. "The essence of success in the merchandising of all the art: is in new tellings of old stories. There are no new ideas, but some of the old ones ar pretty good yet." Editorial in Motion Picture Herald, April 23, I938, p. 7.

55. Holmes v. Hurst, 174 U. S. 82, 86 (I899).

56. Jefferys v. Boosey, $4 \mathrm{H}$. L. Cas. 815, 867 (I854). Parke, B., made the cogen remark that "it would tend to keep our ideas clear . . . if, instead of copyright, $i$ was called the exclusive right of printing a published work. . . " Id. at 920 . 
No one supposes, at the present day, that for a play or motion picture to be an infringement of a novel it is necessary to show identity of verbiage in a single line of dialogue. The "copying", the courts have said, which constitutes infringement in such cases is a copying of "the theory of the play", 57 of "the fundamental theme",58 of "the action" "59 or of the "expression". ${ }^{60}$ The observation of Judge Hough that "theme' is not a word of art" " ${ }^{21}$ sufficiently disposes of all these concepts of what it is that copyright protects. They merely define that something in words of unknown meaning. His own observation that "copying which is infringement must be something "which ordinary observation would cause to be recognized as having been taken from' the work of another" ${ }^{2}$ is equally subject to criticism. There are many things "which ordinary observation would cause to be recognized as having been taken from' the work of another" which do not constitute infringements of the work of that other. Indeed, the dangerous experiment has been tried successfully of deliberately sitting down with a copyrighted stage play and concocting a screen play designed to incorporate the elements which gave the stage play its popularity without infringing on the copyright of the stage play. ${ }^{63}$

The unsatisfactoriness of the attempts so far made to define what it is that the copyright law protects have recently led to some judicial statements that such a definition is unnecessary.

"The determination in each instance [of copyright infringement] depends so largely upon its own particular group of facts that other cases are not much of a guide." 04

"Whether or not there has been an infringement of a copyright is a question of fact on which previous decisions are not controlling precedents." 65

57. Vernon v. Shubert, 220 Fed. 694,696 (S. D. N. Y. I9I5).

58. Underhill v. Belasco, 254 Fed. 838,842 (S. D. N. Y. I9I8). Cf. “. . . the plaintiff's theme, that is, the basic idea of their Play, would not have been protected. . . " Sheldon v. Metro-Goldwyn Pictures Corporation, 7 F. Supp. 837, 843 (S. D. N. Y. I934), rev'd, 8I F. (2d) 49 (C. C. A. 2d, 1936), cert. denied, MetroGoldwyn Pictures Corp. v. Sheldon, 298 U. S. 669 (1936). ". . - the theme was too generalized an abstraction" to be protected. Nichols v. Universal Pictures Corporation, 45 F. (2d) II9, I22 (C. C. A. 2d, 1930), cert. denied, 282 U. S. 902 (I93I).

59. Frankel v. Irwin, 34 F. (2d) I42, I43 (S. D. N. Y. I9I8).

60. ". . . the defendants were entitled to use, not only all that had gone before, but even the plaintiffs' contribution itself, if they drew from it only the more general patterns; that is, if they kept clear of its 'expression'". Sheldon v. Metro-Goldwyn Pictures Corporation, SI F. (2d) 49, 54 (C. C. A. 2d, 1936)), cert. dentied, Metro-Goldwsn Pictures Corporation v. Sheldon, 298 U. S. 669 (1936).

6I. Dymow v. Boiton, II F. (2d) 690, 692 (C. C. A. 2d, I926). 2d, rg24).

62. Ibid., quoting King Features Syndicate v. Fleischer, 299 Fed. 533,535 (C. C. A.

63. Nichols v. Universal Pictures Corp., 34 F. (2d) I45 (S. D. N. Y. I929), aff'd, 45 F. (2d) II9 (C. C. A. 2d, 1930), cert. denied, 282 U. S. 902 (193I).

64. Ornstein v. Paramount Productions, 9 F. Supp. 896, 902 (S. D. N. Y. 1935).

65. Park v. Warner Bros., \& F. Supp. 37, 39 (S. D. N. Y. 1934). 
This leaves the law of copyright about where the law of contracts would be if the courts were to announce that "whether or not consideration has been given is a question of fact on which previous decisions are not controlling precedents'. Its practical application comes out in the announcement by one judge, who was called upon to decide whether one musical composition was an infringement of the other, that "the playing of the two compositions . . . carried no identity of melody to me". ${ }^{66}$ Does the law of musical copyright depend on the ear of the judge who happens to hear the case? Should a certain standard of musical appreciation be made a prerequisite of appointment to the federal judiciary? Under the present system the law will necessarily vary from district to district but if stare decisis is irrelevant in copyright is there any reason why res adjudicata should be regarded? Why should not a plaintiff, defeated in one district, be permitted to try the musical taste of a different judge? In short, is there anything about such a system which can be described as law?

In the case from which the last quotation was made the judge did not rely entirely on his ear. He also leaned heavily on expert testimony. This was contrary to the general policy of the courts which has been to frown on expert testimony in such cases. The reason is obvious. Some derivation is legal; other derivation is illegal. The only kind of an expert who can determine in which class a particular instance of derivation falls is a legal expert. A musicologist may be able to say whether there was musical plagiarism; perhaps the question whether it was justified should be referred to a moralist, ${ }^{\text {or }}$ but only a lawyer can say whether a particular plagiarism was or was not legal.

Perhaps the neatest illustration of the problems in these derived products cases is found in Witwer $v$. Harold Lloyd Corporation. ${ }^{68}$ In that case the plaintiff, Witwer, wrote a short story which he sold to a magazine publisher for $\$ 75$. Subsequently the publisher reassigned the copyright to Witwer for a nominal consideration. Nearly a decade after the publication of the short story the defendant produced the motion picture which was alleged to infringe the short story. The defendant then caused a novel to be written and published which purported to be a "version" of the motion picture. At the time when the

66. Hirsch v. Paramount Pictures, Inc., I7 F. Supp. 8r6, 8 8 (S. D. Cal. I937).

67. "Walter Scott benutzte eine Scene meines 'Egmont', und er hatte ein Recht dazu, und weil es mit Verstand geschah, so ist er zu loben." I EckERMANN, Gespräche Mit Goethe (4th ed. I876) I33. Edwards, Plagiarisar (I933) (which has as its subtitle "An Essay on Good and Bad Borrowing") is an excellent defense of the proposition that plagiarism may sometimes be morally justifiable.

68. 46 F. (2d) 792 (S. D. Cal. I930), reø'd (one judge dissenting), Harold Lloyd Corporation v. Witwer, 65 F. (2d) I (C. C. A. 9th, I933), cert. dismissed, 296 U. S. 669 (1935). 
motion picture was produced Witwer was accustomed to receive about $\$ 1,000$ for the motion picture rights to one of his stories. The cost of making the motion picture was about $\$ 330,000$. The profits from the picture were admitted by the defendant to be over $\$ 1,000,000$ and were alleged by the plaintiff to be even greater. To add to the difficulty, the picture was a "cuffo production", that is, there was no scenario or other script, the plot being made up orally by the makers of the picture as they went along. Of the four judges who had occasion to pass on this case, two thought the picture was an infringement of the short story, two that it was not. Both the district court opinion and the majority opinion of the circuit court of appeals contain synopses of the short story and the motion picture. The reader who peruses either of these opinions alone will probably be convinced of the soundness of its conclusion. The experiment will be enlightening. Most opinions in cases of literary or dramatic copyright infringement proceed by the same method, but it is seldom that we are favored with more than one judicial analysis of the stories in conflict. One of the lessons of the Witwer case is that there may be two equally legitimate synopses of a story, one of which may point to infringement and the other to non-infringement; that however sound a judicial opinion on copyright infringement may appear when read there is always the possibility that a different judge might have analyzed the two plots in conflict so as to make a different conclusion appear equally sound.

The most surprising thing about this case is that the district court, while it held the picture to be an infringement of the short story, held that the novel was not such an infringement. So far as appears from the reports, the legal possibility of this result seems to have been admitted by the parties and the appellate court. Yet the more it is considered the stranger it appears. The assumption which underlies the law giving the owner of a copyright rights to the various "versions" of his property is that the medium is a mere outer covering or wrapping. Turning a novel into a play or a play into a novel is considered as analogous to taking a piece of physical property out of a blue envelope and putting it into a white one. This was clearly the conception of Justice Holmes in the opinion establishing the existence of "motion picture rights" in a novel.

"It is suggested that to extend the copyright to a case like this is to extend it to the ideas, as distinguished from the words in which those ideas are clothed. But there is no attempt to make a monopoly of the ideas expressed. The law confines itself to a particular, cognate, and well-known form of reproduction." 69

69. Kalem Co. v. Harper Bros., 222 U. S. 55, 63 (rgII). 
Yet here we have a court holding that if $B$, without the permission of $A$, takes the property out of $A^{\prime}$ s envelope and puts it into his own the taking is wrongful and the property must be returned, but if $B$, having taken $A$ 's property, wrongfully, hands it to $C, C$ has a lawful title and may keep it. The only way this result can be justified is to assume that the property covered by the copyright to the novel and the property covered by the copyright to the short story were not the same. The court held that the property covered by the copyrights to the short story and the motion picture were the same so the only place the change of properties could have occurred was in the conversion of the motion picture into a novel.

This brings us to the central problem in all questions of copyright infringement between works in different media. Justice Holmes to the contrary notwithstanding, a motion picture is never a mere "reproduction" of a novel, a short story or a play nor is a stage play a mere "reproduction" of a novel nor a novel of a stage play or a motion picture. The final result in the Witwer case was quite clearly influenced by a consideration of the absurdity of giving a plaintiff one million dollars or more as compensation for the taking of something having a market value of one thousand dollars. To ascribe the profits of the motion picture to Witwer's story rather than to Lloyd's acting certainly ran counter to the business judgment evidenced by these figures. If anything could be a "particular, cognate and well-known form of reproduction" of the motion picture it should have been the novel. It was written for the express purpose of being such a reproduction yet it was held not to be. The motion picture claimed to have no relation to the short story yet two out of four judges thought it was a "reproduction" and the conclusion of the other two was based largely on the fact that they were not satisfied that the makers of the motion picture had ever read the short story. It is obvious that what we have here is something very different from the production of a suit of clothes from a pattern or a house from a blue print. In those cases presumably if someone subsequently draws a pattern from the suit of clothes or makes a blue print from the house the relationship between the second pattern or blue print and the original ones will be apparent. The inarticulate assumption in Justice Holmes' statement is that it requires merely mechanical skill to turn a story into a motion picture. This assumption cannot be justified. But yet, the statute clearly contemplates the possibility of the infringement of a story by a motion picture. What criteria can be established for determining whether there is such infringement? 
The traditional conception of copyright was quite clear. The thing protected was the way the story was told, not the story itself. The way the story was told was not conceived of as the "plot", the "theme", the "expression" or the "pattern", but as the verbiage-the order of words. Even a translation was not regarded as an infringement. $^{70}$ Nor was a synopsis so regarded. ${ }^{71}$ "Plots", what are now called in the amusement business "stories", were regarded as of no more importance in literature than in music. The novelist, like the composer of operas, regarded the story, the libretto, as a mere detaila traditional frame on which to display his own work.

This conception of the nature of the property interest protected by copyright obviously precluded the possibility of a stage play being an infringement of a novel merely because the "story" and the title of the novel and of the play were the same. Infringement could only be established in the unlikely contingency that a substantial amount of the verbiage in the novel and in the play were identical. In the nineteenth century the profits of successful playwrights seem to have been much in excess of the profits of successful novelists. ${ }^{72}$ Naturally, this state of the law did not sit well with the novelist who saw someone make more than he had by writing a play the title and plot of which were derived from his novel. He called it "thievery" and, when the law began to change, legal literature is full of references to "felonious intent" as an element in copyright infringement.

This is not the place to discuss literary trends but a few words may be in order. Shakespeare, as everyone knows, "never invented a plot", ${ }^{73}$ but it is safe to say that he did not therefore have animus furandi. This change of conception among authors as to what it is that constitutes "literary property" was a result of the substitution of the canons of romanticism for those of classicism as the criteria of literature. Classicism assumed that literary excellence had some relation to scholarship-that inborn genius could not result in literature except in conjunction with learning and culture. It admired Shakes-

70. Stowe v. Thomas, 23 Fed. Cas. No. I3,5I4 (C. C. E. D. Pa. 1853) (German translation of Uncle Tom's Cabin). "To call the translations [sic] of an author's ideas and conceptions into another language, a copy of his book, would be an abuse of terms, and arbitrary judicial legislation." Id. at 207.

71. Story v. Holcombe, 23 Fed. Cas. No. I3,497 (C. C. D. Ohio, I847) (abridgment of Story's Equity-McLean, J., indicated a strong dislike of the doctrine, but considered himself bound by precedent); Lawrence v. Dana, 5 Fed. Cas. No. 8, I36 (C. C. D. Mass. I869) (notes to Wheaton's Elements of International Law-Lawrence subsequently obtained revenge by blocking confirmation of Dana's appointment as minister to England); see Webb v. Powers, 29 Fed. Cas. No. 17,323 at 519 (C. C. D. Mass. I847).

72. BirReLx, Copyright (I899) I55.

73. EDWARDS, Plagiarisar (I933) 29; of. "For everything is in the telling, he said. The poets write twenty different plays on the same subject; everything is in the telling. - . " GEORGE MOORE, APHRodite IN AULIS (N. Y. I93I) I8I. 
peare and Homer but it lamented their "rudeness". Dr. Johnson thought Pope's Homer an improvement on the original ${ }^{74}$ and Voltaire revised Shakespeare to conform to the Gallic version of Aristotle's canons. ${ }^{75}$ Romanticism went to the opposite extreme. Scholarship, it maintained, could never result in the production of great literature. The test of genius was originality and only the complete ignoramus could be completely original. Culture could not grow by itself but could only be advanced by stevedores, soda jerkers and South Sea islanders.

The importance of this theory to the law of copyright is apparent. Anything a perfect ignoramus produces must of necessity be original with him, that is, original in the copyright sense. Since he knows nothing he must have invented not only his own verbiage but his own plot. Since he invented both, why should he not have as good a legal title to the plot as to the verbiage? It is true that the complete ignoramus is seldom a party to copyright litigation, but when the premise has once been accepted that literary genius consists not in the beauty of diction but in the originality of conception, the semiignoramus will have no difficulty in convincing himself that his plot is original with him.

This fundamental change in the conception of what constitutes literary excellence underlies the law of what are here called "derived products". Both the pressure on the law arising from this change in literary values and the reason for the length of time that it took that pressure to become effective can be brought out by an excerpt from an excellent book on the law of copyright published about the time the statutes were modified both in England and America to recognize "dramatization rights".

"It is now generally admitted that the unauthorized dramatization of novels should be prohibited, but I expect it will be found difficult to do more than prevent the bodily appropriation by the dramatist of the ipsissima verba of the novelists [sic]. Plots, situations and scenes have been the common property, both of novelists and dramatists, for so long a time that to attempt to set them out now by metes and bounds between the hosts of rival claimants would tax even the lettered intellect of a judge of the Chancery Division." 76

This warning did not prevent the courts, when the statutes were amended, from attempting to set out the metes and bounds between

74. I Macaulay, Critical and Historicat Essays (Houghton, Mifflin ed.) 733. It is probably unnecessary to point out that subsequent scholarship has destroyed the assumption that Homer's works were the products of untutored genius.

75. MaUrois, VoltaIre (trans. I933) 42-43.

76. Birrelt, Copyright (I899) I57-158. 
plots, situations and scenes, but anyone who surveys the results of that attempt will be likely to conclude that the warning was properly given. Neither the English nor the American statutes required the attempt to be made. In both cases the amendments seem to have been passed with a complete disregard for the traditional conception of what it is that copyright protects. This new branch was grafted on without any attention being paid to the species of tree on which it was being grafted. So far as the legislators were concerned this must be ascribed to the change in the popular conception of literary values between a century which regarded Pope, and a century which regarded Shelley, as the great example of literary genius. Romanticism has done its work so well that even those who should know better do not always seem to realize that the word "copyright" today refers to a fundamentally different kind of property from that to which it referred a hundred years ago. Only a persistent determination to view all legal principles as outgrowths of the yearbooks can justify the statement found on the first page of the most recent edition of the leading treatise on copyright law that "extensions of the law of copyright have all consisted in bringing works other than 'books' within the principles of the same law." 77

The practical difficulties in the application of these amendments were obscured by the fact that abstract discussions of copyright always tend to be conducted on the plane of "If both works were copyright, would Goethe's Faust be an infringement of Marlowe's Dr. Faustus?" while the practical problem is more likely to be, "Did one vaudevillian swipe a gag from another?" Birrell's remark is still true that "in reading the cases in the Reports for the last hundred years, you cannot overlook the literary insignificance of the contending volumes" 78 and Judge Learned Hand's opinion in the Abie's Irish Rose case ${ }^{79}$ brings out quite clearly the difficulties of applying principles derived from a consideration of the classics to the determination of questions of infringement in "pulp" literature:

"If Twelfth Night were copyrighted, it is quite possible that a second comer might so closely imitate Sir Toby Belch or Malvolio as to infringe, but it would not be enough that for one of his characters he cast a riotous knight who kept wassail to the discomfort of the household, or a vain and foppish steward who became amorous of his mistress." so

77. Copinger, Copyrught (7th ed. 1936) I.

78. BiRrell, Copyright (I899) I70-I7I. Cf. "A line may be stolen; but the pervading spirit of a great poet is not to be surreptitiously obtained by a plagiarist. The continued imitation of twenty-five centuries has left Homer as it found him." I MACAULAY, op. cit. supra note 74 , at 35 .

79. Nichols v. Universal Pictures Corp., 45 F. (2d) II9 (C. C. A. 2d, I930), cert. denied, 282 U. S. 902 (I93I).

8o. Id. at I2I. 
In the play before the court, Judge Hand pointed out, "The lovers are so faintly indicated as to be no more than stage properties. They are loving and fertile; that is really all that can be said of them. . . ." 81

The statutory provisions in the United States providing for what are here called "derived products" have left the courts at complete liberty to work out their own principles for the determination of what products are "derived". Thus the most important of those provisions gives the owner of a copyright the exclusive right

"To translate the copyrighted work into other languages or dialects, or make any other version thereof, if it be a literary work; to dramatize it if it be a nondramatic work; to convert it into a novel or other nondramatic work if it be a drama; to arrange or adapt it if it be a musical work. . . ." 82

If the courts had been so inclined they could easily have followed, under this statutory provision, Birrell's suggestion quoted above. A version could have been limited to a colorable imitation of the diction of the prior copyrighted work ${ }^{83}$ and a dramatization to the use of ipsissima verba or to a work which purported by the use of the same title or the same names of characters to be a dramatization. Similar principles could have been applied to a "novelization" of a drama or an adaptation of a musical work. That the courts did not do so can be ascribed in part to the pressure arising from the change in the canons of literary criticism and in part to the example of the already expanding field of copyright by-products, but, above all, to a failure to realize the difficulty of the problems which were going to arise. Part of these difficulties arose from the peculiar copyright meaning of "original" but, as the cases cited earlier show, ${ }^{84}$ that meaning of "original", while not exactly new, is not so firmly embedded in the law as to prevent judges from occasionally overlooking it.

The statutory changes have compelled a departure from the traditional conception of a literary copyright as a right to the verbiage or diction but have given no inkling of the principles on which the new conception is to be based. The attempt to treat the new copyright as a right to the "story", "theme" or "plot" (none of which are words of art) has not only raised great practical difficulties; it runs head on into one of the most firmly established of legal principles, the principle that a copyright cannot cover an idea, a system. ${ }^{85}$ A few of the more

8I. Id. at $\mathrm{r} 22$.

82. 35 Stat. I075 (I909), I7 U. S. C. A. § I (b) (1927).

83. Encyclopaedia Britannica Co. v. American Newspaper Ass'n, 130 Fed. 460 (C. C. D. N. J. I904), is an example of colorable imitation of diction.

84. See supra note 3.

85. Baker v. Selden, тог U. S. 99 (1880) ; Griggs v. Perrin, 49 Fed. I5 (C. C. N. D. N. Y. I892); see Burk v. Johnson, I46 Fed. 209, 2I3 (C. C. A. 8th, Ig06). The 
recent opinions seem to recognize the truth that in protecting "stories", "themes" or "plots" the courts are really protecting ideas, that the rule is not that ideas are not protected but that for ideas to be protected they must be specific rather than general. ${ }^{86}$ Yet even this interpretation of the traditional rule can only be accepted hesitantly and with qualifications. Certainly no support for it can be found in any of the cases ${ }^{87}$ denying copyright protection to "systems", for in most instances those systems are specific enough.

\section{What is a Copyright?}

Are there any principles by which a lawyer, confronted with a copyright, can determine the metes and bounds of the property which it covers? What must he consider in telling a client whether he can "base" a dance on a cartoon strip or use an "idea" from a novel in the manufacture of furniture? If lucky, the lawyer may be able to find a precedent for the specific problem but, even if he is so fortunate, what criteria can he apply to determine the value of the precedent? Will the law of copyright continue its apparent tendency to develop different lines of precedent dependent on the form in which the work is originally copyrighted? Can it do so in view of the increasingly protean nature of those works? Is it not necessary to stop thinking in terms of a copyright of a novel, a cartoon, a photoplay, a screen play, a painting or a poem, and think instead in terms of "copyright" in the abstract? Can all these specific copyrights and independent threads of authority be reduced to one fundamental conception?

The statute, it is true, does not contemplate any such fundamental conception, but the statute is about as useful to a lawyer confronted with these questions as a copy of Quia Emptores is to a modern conveyancer. The whole field of what are here called copyright byproducts is extra-statutory, and, while most of what ate here called derived products now have statutory recognition, it is significant that the most important of them, motion pictures, was recognized by the courts before it was mentioned in the statute. ${ }^{88}$ The present judicial tendency is clearly to increase both fields without awaiting statutory recognition. But it is rather difficult to determine the direction of

more recent cases, Affiliated Enterprises v. Gantz, 86 F. (2d) 597 (C. C. A. Ioth, 1936), and Affiliated Enterprises v. Gruber, 86 F. (2d) 958 (C. C. A. Ist, 1936), reiterate the principle, but their authority is weakened by doubt whether the ideas for which protection was asked were not contrary to public policy.

86. See Nichols v. Universal Pictures Corp., 45 F. (2d) IIg, I2I (C. C. A. 2d, I930) ; Sheldon v. Metro-Goldwyn Pictures Corp., 8I F. (2d) 49, 54 (C. C. A. 2d, I936).

87. See supra note 85 .

88. Kalem Co. v. Harper Bros., 222 U. S. 55 (IgII). 
that tendency without some tests for determining the nature of the property to which a copyright gives title.

A broad division may be made between works of "artistic" skill and works of drudgery. Little criticism can be made of the cases dealing with controversies between rival map-makers, directory makers and legal-digest makers but it only tends to confusion to treat this group of problems under the same heading as disputes between the creators of an animated cartoon and a manufacturer of furniture or between a novelist and a motion picture producer. The proper classification of the legal protection given to works of drudgery would seem to be under some heading in that field of law which we are learning to call "Restitution".

What the infringer of a work of drudgery takes is entirely different from what an infringer of a work of artistic skill takes. The business values which are appropriated in the latter case fall into two classifications: first, ideas; and, second, popularity value. The only workable concept of the nature of the property rights covered by a "copyright" of works of "artistic" skill must be based on a recognition of these business values as being likewise the fundamental legal "rights" contained in a copyright. When this is done we can expect the minor rules for determining infringement rapidly to fall into an intelligible pattern. The talk about unfair competition will be discarded as it ought to have been long ago and, in all probability, very different legal attitudes will arise for determining infringement when the question is one of the purloining of a business idea and when the question is one of the purloining of popularity value. The protection given to popularity value will increase for the reasons that it will be comparatively easy to trace its purloining and that no principles of policy will operate for the protection of the purloiner. The protection given to ideas, on the other hand, may be expected to become limited to the most flagrant instances. A good case could be made for the limitation of this type of protection to ideas contained in unpublished works on some analogy to the doctrines protecting business secrets. Little can be said in favor of the extensive protection of ideas in copyright which has prevailed in the last few decades. Combined with the doctrine that the idea, to be protected, need not be an invention, it has produced something remarkably close to a racket. Nor is it of much use in promoting "the Progress of . . . useful Arts". The most obvious practical effect of this legal tendency has been greatly to increase the difficulties of unknown authors, composers and dramatists, in other words, to prevent the progress of useful arts. The producer who has once had to bear the expense of defending an infringement suit, even 
if successful in his litigation, is not likely again to run the risk of opening an envelope from an unknown which appears to contain a manuscript.

The courts, in attempting to work out methods for ascertaining whether "plots", "situations", "themes" and "characters" have been purloined, have been attempting to introduce exactness into a field in which there are no materials on which to base it. It is an attempt to find the algebraic equation which accounts for popular fancy. When the entertainment business ceases to be a lottery, perhaps the law will be able to make some progress in this direction. In the meantime it would be better to treat popularity value as the primary element in copyright and to avoid attempting to set out the metes and bounds of plots, situations and characters. 